\title{
PERANCANGAN SISTEM PELAYANAN ADMINISTRASI KEPENDUDUKAN DESA BERBASIS WEB DENGAN PHP \& POSTGRESQL
}

\author{
Dony Susandi $^{1)}$, Dede Abdurrahman ${ }^{2)}$, Aceng Kusaeri ${ }^{3)}$, Hafidz Sanjaya ${ }^{4)}$ \\ Program Studi Teknik Industri, Fakultas Teknik, Universitas Majalengka ${ }^{1)}$ \\ Program Studi Informatika, Fakultas Teknik, Universitas Majalengka ${ }^{2)}$ \\ Email :dys@ft.unma.ac.id, dea@ft.unma.ac.id, acekus@gmail.com, hafidzsanjaya@ft.unma.ac.id
}

\begin{abstract}
Population administration services is very important not only to the process of improving the quality of a village, but it is also used to measure the level of community satisfaction with services received. The background of this study is the lack of applications waiter population administration village resident can import data into the system, which makes the process less effective in time for data collection ever increasing population.

Application design using RUP (Rational Unified Process), consists of 4 stages: Inception, Elaboration, Consturction, and Transition. System made by UML modeling, consists of a use case diagrams, activity diagrams, and sequence diagrams.The result of this research are SPAPenDes application, to manage the population data. The resulting system has several menu, namely: family data, population data, event data, statistics and reports.
\end{abstract}

Keywords: unified Modelling Language, RUP, SPAPenDes.

\section{Pendahuluan}

Menurut Kemendagri No. 37 Tahun 2006 Pelayanan Administrasi di desa terbagi 6 yaitu: Administrasi Umum, Administrasi Penduduk, Keuangan, Administrasi Pembangunan, Administrasi BPD dan Administrasi Lainnya. Administrasi penduduk adalah kegiatan pencatatan data dan informasi mengenai penduduk dan mutasi penduduk pada Buku Administrasi Penduduk yang terdiri dari Buku Data Induk Penduduk Desa, Buku Data Mutasi Penduduk Desa, Buku Data Rekapitulasi, Jumlah Pendudukan Akhir Bulan dan Buku Data Penduduk Sementara (Sofyan, 2015).

Informasi kependudukan merupakan faktor utama dalam pemerintahan desa. Dengan berkembangnya suatu desa, maka populasi penduduk akan semakin meningkat dan menyebabkan sulitnya proses pendataan penduduk. Menurut UU No. 6 Tahun 2014 Tentang Desa, Desa berkewajiban diantaranya melindungi dan menjaga persatuan, kesatuan serta kerukunan masyarakat desa dalam rangka kerukunan nasional dan keutuhan NKRI. meningkatkan kualitas kehidupan masyarakat desa, mengembangkan kehidupan demokrasi, mengembangkan pemberdayaan masyarakat desa, serta memberikan dan meningkatkan pelayanan kepada masyarakat desa (Firman, Dian, \& dkk. 2014).
Pelaksanaan pelayanan kepada masyarakat desa harus didukung dengan adanya sumberdaya manusia aparatur yang memadai baik secara kuantitas maupun kualitas, serta tersedianya sarana prasarana dan fasilitas pelayanan yang baik. namun masih banyak kekurangan dalam hal sarana dan prasarana. Oleh karena itu, pemerintah melakukan upaya untuk meningkatkan mutu dan pelayanan kepada masayarakat yaitu dengan dibuatnya aplikasi sistem informasi desa. Tetapi dijumpai beberapa kekurangan pada aplikasi yang dikembangkan oleh pemerintah ini diantaranya yaitu tidak tersedianya menu impor data sehingga perangkat desa harus meng-input data penduduk satu per satu ke dalam aplikasi.

\section{Metode Penelitian}

Untuk memudahkan pemahaman tahapantahapan yang penulis lakukan dalam penelitian ini maka dibuatlah kerangka penelitian. Kerangka penelitian tersebut dapat dilihat pada gambar 1 . 


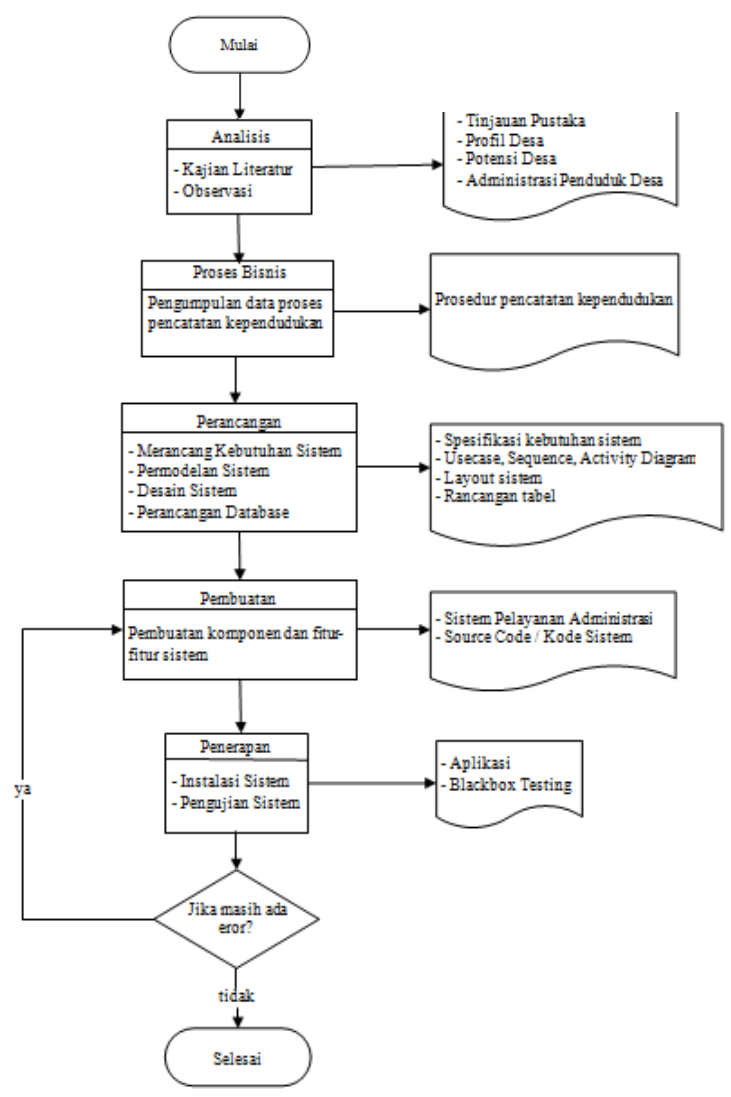

Gambar 1. Tahapan Penelitian

Dalam kerangka penelitian ini, terdiri dari 5 tahap yaitu sebagai berikut :

1. Tahap Analisis

Pada tahap pertama penelitian penulis melakukan kajian literatur yang memiliki tema penelitian yang sama, untuk membandingkan sistem yang sebelumnya pernah dikaji dengan sistem yang akan dibuat sehingga menghasilkan sebuah sistem yang lebih up-todate dan mengatasi kekurangan yang sering muncul secara fungsional pada objek penelitian. Beberapa jurnal yang diresume adalah sebagai berikut :

1) Dedi Prasetyo $N$ tahun 2013 dengan judul Perancangan Pendataan Kependudukan Desa Sugihwaras;

2) Syarif Hidayatulloh dan Cisde Mulyadi tahun 2015 dengan judul Sistem Pelayanan Administrasi Kependudukan Desa Candigatak Berbasis Web;

3) Erik Septiana tahun 2013 dengan judul Pembuatan Website Desa Sukaraja sebagai Sarana Peningkatan Informasi Masyarakat.

Selain kajian literatur, pada tahap analisis penulis juga melakukan observasi untuk mengetahui profil, aktifitas, potensi dan administrasi penduduk. Hasil observasi yang dilakukan yaitu berupa data profil desa, potensi desa, dan administrasi penduduk.

2. Proses Bisnis

Pada tahapan ini ada beberapa proses yang dilakukan dalam pencatatan penduduk, diantarnya proses penerbitan kartu keluarga, proses pencetakan surat keterangan/pengantar.

1) Persyaratan administrasi pencatatan kartu keluarga baru :

a. Photo copy KTP keluarga;

b. Photo copy kutipan akta nikah/perkawinan atau akta cerai;

c. Photo copy kutipan akta kelahiran.

2) Pencetakan surat keterangan/pengantar

a. Photocopy KTP;

3) Persyaratan pencatatan peristiwa (kelahiran, kematian dan data pindah)

a. Pencatatan data kelahiran;

b. Photocopy KK;

c. Photocopy surat nikah;

d. Surat keterangan kelahiran dari dokter;

Setiap data yang disimpan pada sistem akan disesuaikan dengan data yang tertera pada masing-masing berkas yang dijadikan persyaratan.

3. Perancangan

Pada tahap ini sistem dibuat dengan beberapa tahap perancangan seperti menentukan spesifikasi hardware dan software yang dibutuhkan untuk membuat aplikasi, pemodelan sistem dengan menggunakan UML, merancang desain antarmuka aplikasi dan merancang database yang ada pada sistem yang akan dibuat.

4. Pembuatan

Pada tahap ini sistem dibuat berdasarkan rancangan yang ada. Hasil dari tahap ini berupa aplikasi sistem pelayanan administrasi kependudukan di desa.

5. Penerapan

Dalam tahap ini sistem dilakukan pengujian terlebih dahulu. Pengujian yang dilakukan pada tahap ini adalah black box testing untuk mengamati hasil eksekusi melalui data uji dan memeriksa fungsional dari sistem yang telah dibuat.

\section{HASIL DAN PEMBAHASAN}

1. Usecase Diagram

Pada tahap ini usecase diagram digunakan untuk mengambarkan aktor-aktor yang ada pada sistem beserta tingkah lakunya maupun 
interaksi antara satu aktor dengan aktor lainnya. Usecase diagram sistem dapat dilihat pada

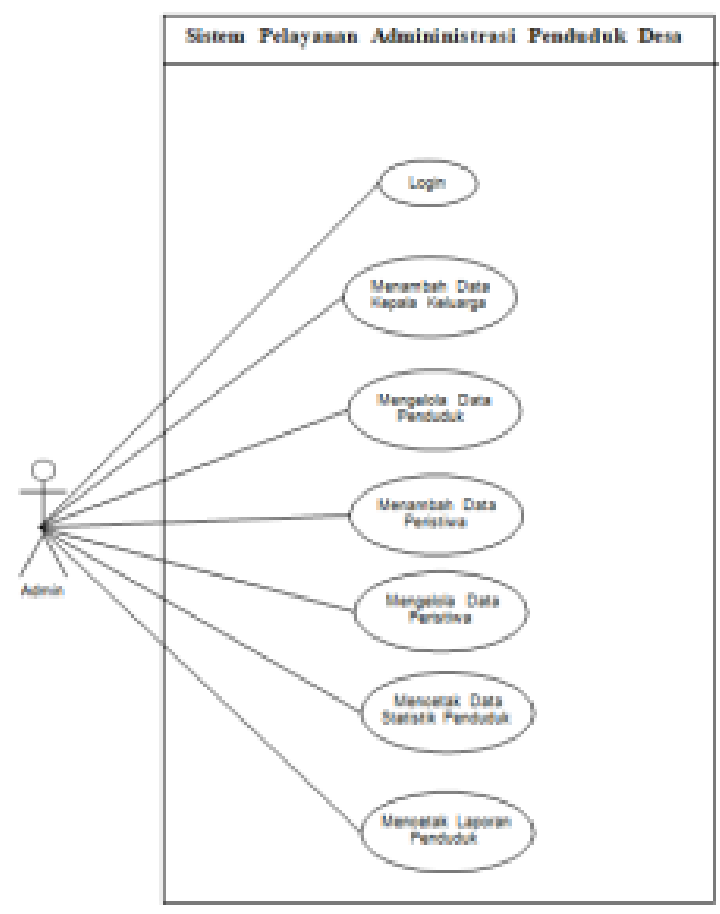

Gambar 2. Use Case Diagram

2. Activity Diagram

Pada tahap ini digambarkan proses bisnis dari sistem dan urutan aktivitas dalam sebuah proses yang memperlihatkan urutan aktifitas proses pada sistem. Activity diagram dapat dilihat pada gambar 3 .

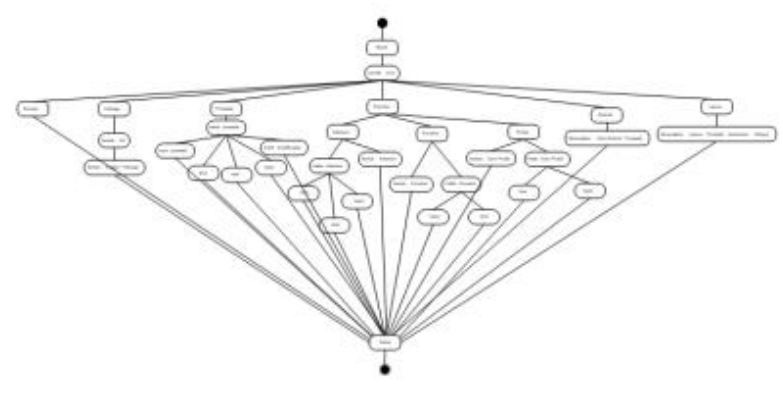

Gambar 3. Activity Diagram

3. Sequence Diagram

Sequence diagram digunakan untuk menunjukan rangkaian pesan yang dikirim antara objek satu dengan objek lainnya.

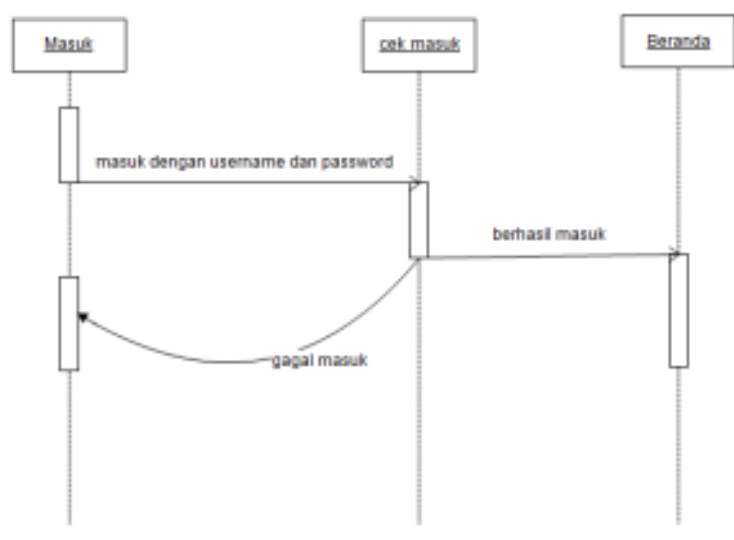

Gambar 4. Sequence Diagram Proses Masuk

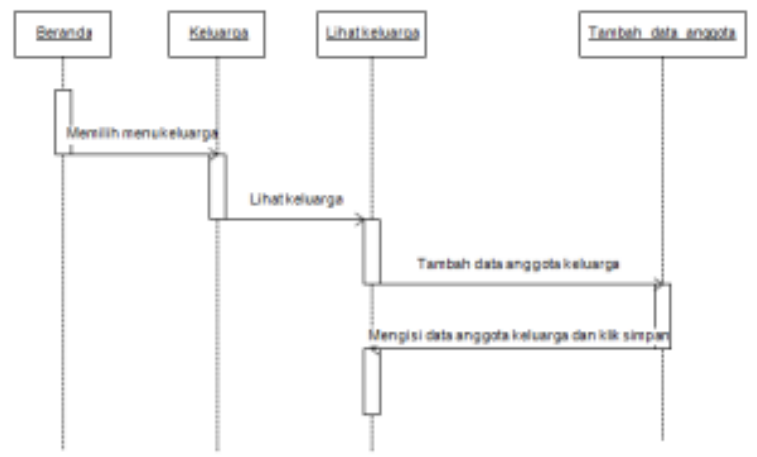

Gambar 5. Sequence diagram proses tambah data kepala keluarga

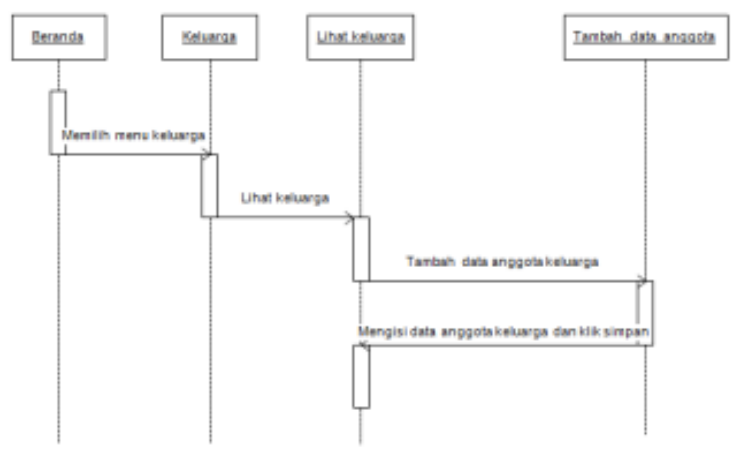

Gambar 6. Sequence diagram proses tambah data anggota keluarga 


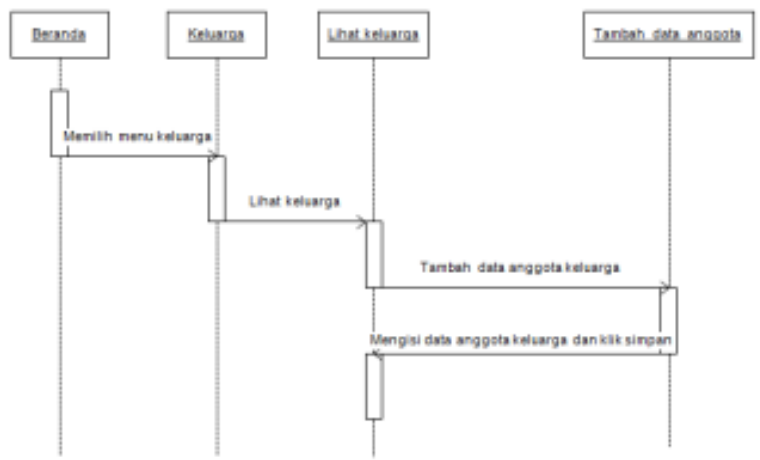

Gambar 7. Sequence diagram proses cetak kartu keluarga

4. Implementasi Sistem

Sistem layanan administrasi kependudukan desa dapat diakses ketika user atau pengguna login terlebih dahulu.

Pada halaman awal sistem menunjukkan halaman login pengguna, setelah berhasil login, pengguna dialihkan ke halaman beranda terdapat beberapa fitur yang dapat diakses oleh pengguna diataranya kalkulasi jumlah penduduk laki-laki dan perempuan. Beberapa menu pada sistem yang bisa diakses adalah beranda, keluarga, penduduk, peristiwa, statistik, laporan dan pengaturan.

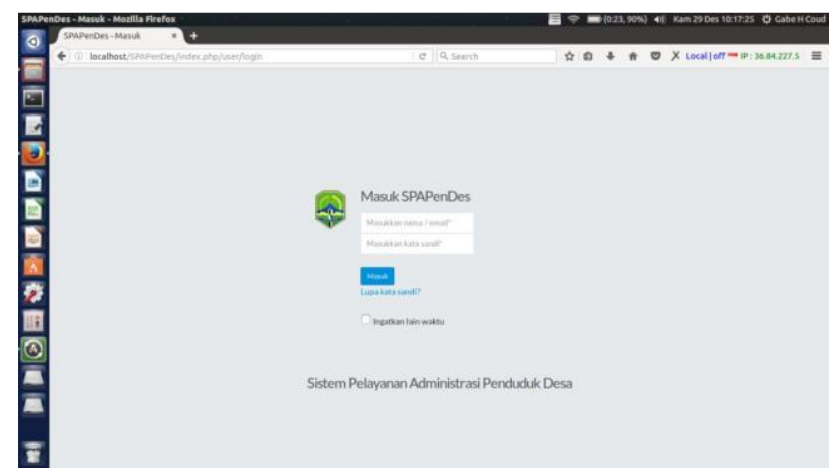

Gambar 7. Halaman Login

Pada browser admin dapat mengakses aplikasi melalui URL: localhost/SPAPenDes, lalu admin akan diarahkan ke halaman login seperti pada gambar 7 .

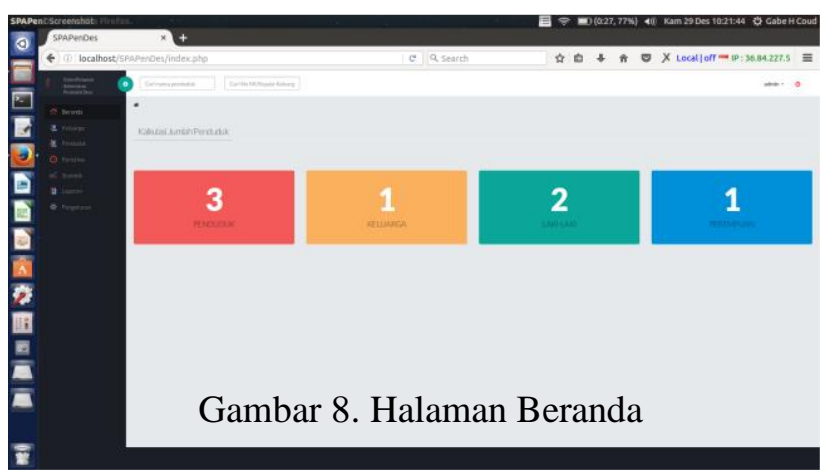

Setelah berhasil masuk ke sistem dialihkan ke halaman beranda, dimana pada halaman ini terdapat kalkulasi jumlah penduduk, keluarga, jumlah penduduk laki-laki dan perempuan. Pada halaman ini hanya menampilkan kalulasi jumlah penduduk.

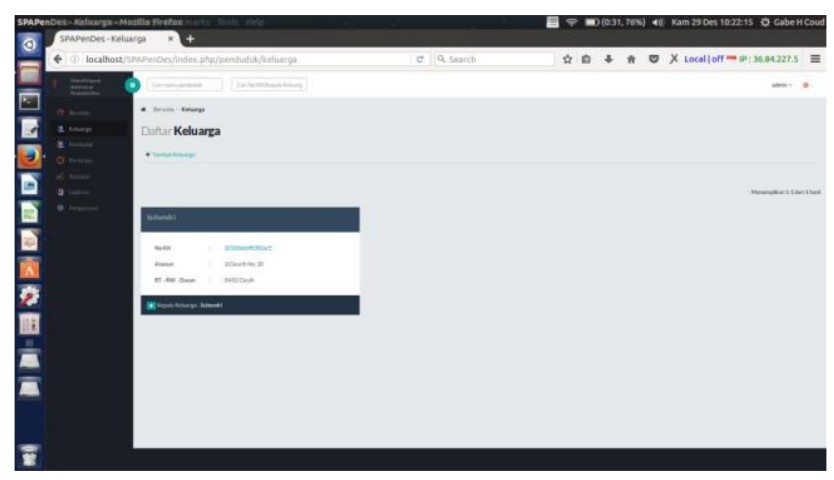

Gambar 9. Halaman Keluarga

admin dapat melihat data keluarga yang telah dimasukan ke dalam sistem, semua data ditampilkan berdasarkan kepala keluarga, jika admin membutuhkan data anggota keluarga admin harus memilih data kepala keluarga terlebih dahulu kemudian data anggota keluarga akan ditampilkan.

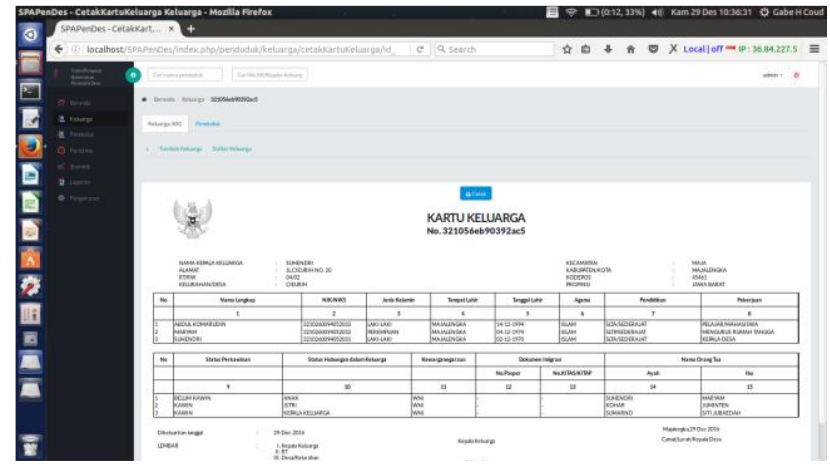

Gambar 10. Tampilan Cetak Kartu Keluarga

Computer Science | Industrial Engineering | Mechanic Engineering |Civil Engineering 
Untuk menampilkannya admin harus memilih kepala keluarga, lalu memilih fitur cetak kartu keluarga dengan menekan tombol cetak dibagian atas tampilan, dengan otomatis kartu keluarga akan tercetak pada printer yang sudah terhubung dengan komputer.

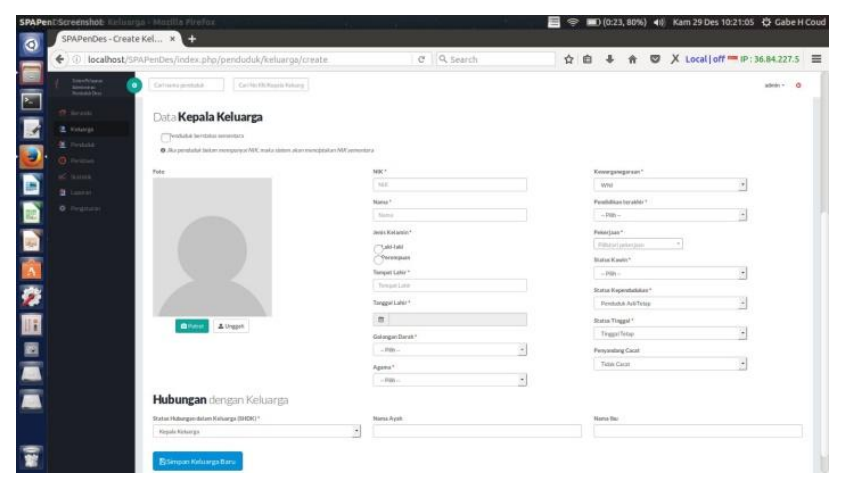

Gambar 11. Halaman tambah data kepala keluarga

Admin dapat menyimpan data jika semua form sudah terisi dengan benar. Jika data NIK sudah ada di dalam sistem, maka admin tidak dapat menyimpan data dengan NIK yang sama, karena NIK merupakan primary key sehingga tidak bisa menyimpan dua data dengan NIK yang sama. Sebelum menyimpan admin dapat memotret kepala keluarga dengan fitur yang telah disediakan.

\section{Pengujian Sistem}

Pengujian sistem ini dilakukan untuk mengamati hasil eksekusi melalui data uji dan memeriksa fungsional dari sistem yang telah dibuat. Setelah sistem diuji menggunakan black box testing, sistem secara keseluruhan memenuhi kebutuhan data dan fungsional.

\section{KESIMPULAN}

Sistem pelayanan administrasi kependudukan desa memiliki bererapa keunggulan yaitu dapat manambahkan fungsi baru yang tidak dapat dilakukan secara konvensional seperti menciptakan storage untuk NIK sementara untuk penduduk yang belum mempunyai Kartu Tanda Penduduk (KTP) sehingga lebih mudah untuk dikelola, dapat mengimpor data penduduk sehingga pencatatan data penduduk yang banyak bisa lebih efisien, bersifat user friendly karena mudah digunakan dalam membuat surat pengantar atau keterangan karena hanya perlu menginput No. KTP atau nama dan mudah melihat jumlah data penduduk karena sudah disimpan pada database sehingga mudah untuk dikelola dengan tampilan yang sederhana. yang dapat memudahkan untuk digunakan oleh admin/operator desa.

\section{REFERENSI}

Bowo, E. (2010). Ubuntu From Zero. Jakarta: Jasakom.

Dini. (2015, November 07). 14 Pengertian Sistem Informasi Menurut Para Ahli. Retrieved Januari 24, 2017, from dosenit.com: http://dosenit.com/kuliah- it/sisteminformasi/pengertian-sistem-informasimenurut-para-ahli

Firman, S., Dian, A., \& dkk. (2014). Pedoman Umum Penyelenggaraan Pemerintah Desa Jilid 1. Jakarta: Bee Media Pustaka.

Goldi Gunadi, S. M. (2012, Juli 3). Aplikasi Berbasis Web. Retrieved 11 12, 2015, from Academia.edu:

https://www.academia.edu/4560304/Aplikasi_ Berbasis_Web

Istiyanto, S. R. (2003). Keamanan Akses ke PostgresSQL melalui PHP menggunakan Apache Web Server pada GNU/LINUX. Yogyakarta: ANDI.

Jogiyanto. (1999). Analisis dan Desain Sistem

Informasi: Pendekatan Terstruktur Teori dan Praktek Aplikasi Bisnis. Yogyakarta: ANDI. Jogiyanto. (2001). Analisis Perancangan Sistem Informasi. Yogyakarta: Andi Offset. 